Int. J. Speleol. 13 (1083) pp. 67-72.

\title{
On the Wad-Minerals from the Cavern Environment
}

\author{
Naruhiko Kashima*
}

SUMMARY

The wad-minerals from limestone caves of Yugoslavia, China and Japan were studied. X-ray diffraction analysis revealed that five minerals; birnes

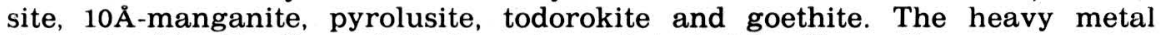
elements, $\mathrm{Mn}, \mathrm{Zn}, \mathrm{Fe}$ and $\mathrm{Cr}$ have been detected by X-ray fluorescence analysis and their contents were roughly determined. The input sources of man. ganese and other metal elements can be proposed to be the condensation water introduced directly from the covering soils formed by the continental weathring, to be the corrosive water introduced reworking from the limestone.

\section{INTRODUCTION}

Recently, many mineralogical studies of the speleo-minerals have been revealed of secondary mineralization in the cavern environment, but there still remain the problem of "wad", which is usually an ill-defined powdery mixture consisting mainly of manganese oxides.

During the investigations of cave minerals, the writer has been sampled some black powdery materials from four limestone caves in Yugoslavia, China and Japan.

The purpose of this paper is to report mineralogical data on some wad-minerals from limestone caves, which have recently recieved attention by mineralogist, and to comment on their genesis.

* Department of Geology, Faculty of General Education, Ehime University. 3 Bunkyo-cho, Matsuyama City, Ehime 790, Japan. 
1) Najdena-jama Cave

Najdema-jama Cave is located in Planinsko polje, Slovenia, Yugoslavia. This cave is developed in Lower Cretaceous dolomites and measures about $4,100 \mathrm{~m}$ in length. The occurrence of manganese minerals in Najdena-jama Cave has already been perceived by Mr. F. Šušteršič. The black to dark brown fine earthy substances occur as thin soft crust (about $5 \mathrm{~mm}$ thick) that covers the cave walls and as fillings in the open-joints of dolomites.

2) Dushu-yan Cave

Dushu-yan Cave in situated in Wuming Xian, Gangxi Zhuang$\mathrm{zu}$ Zizhigu, southern part of China. This cave is one of the small caves in Qifeng-shan cave system. In Dushu-yan Cave, the wad-minerals occur as thin crust of limestone walls of cave passages and the fillings of open-joints and solution pockets.

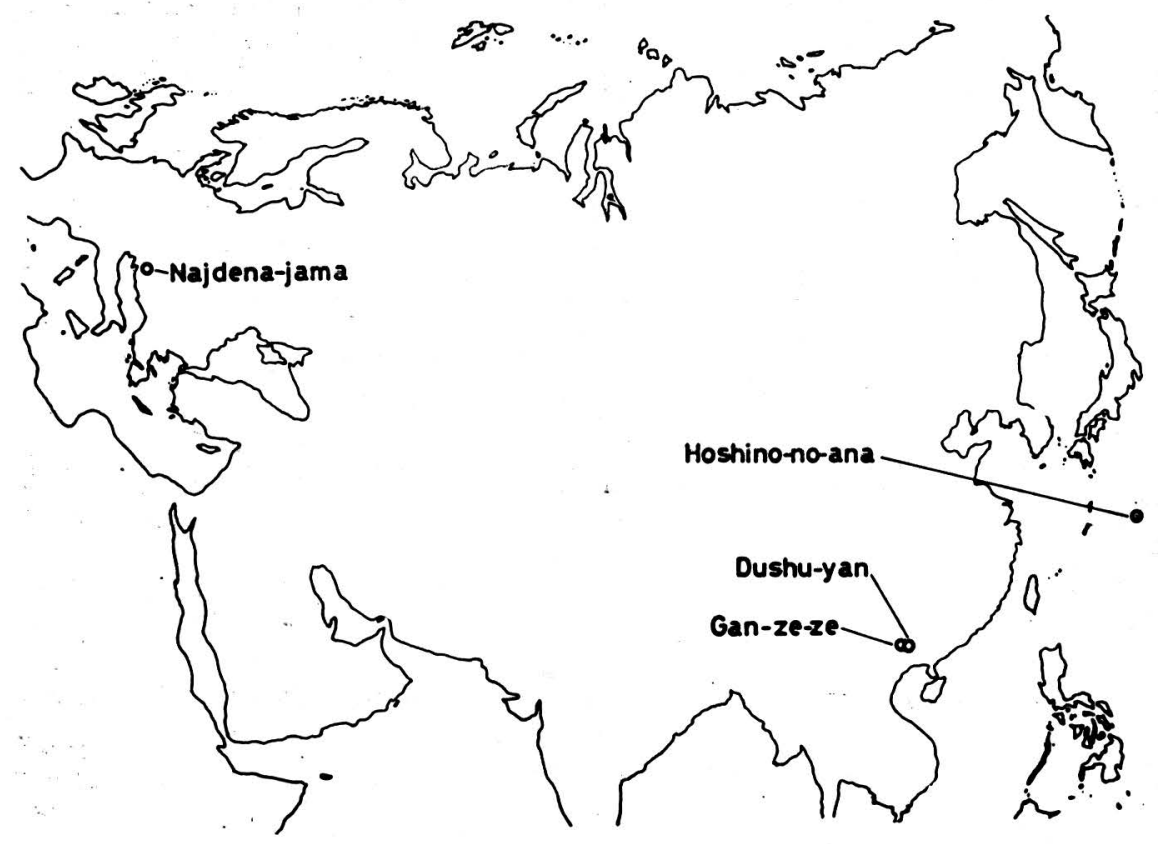

Fig. 1 - Index map of studied caves. 
3) Gan-ze-ze Cave

Gan-ze-ze Cave is located near Qifeng-shan, Wuming Xian, Guangxi Zhuangzu Zizhigu, China. This cave has an estimated $200 \mathrm{~m}$ passages and well developed phosphorate cave minerals. In Gan-ze-ze Cave, wad-minerals occur as black fine earthy materials in the joint openings of limestone walls.

4) Hoshino-no-ana Cave

Hoshino-no-ana Cave was formed in the Quarternary reefal Daito limestones, Minami-daito-jima, Okinawa Prefecture, Japan. The entrance opens about $40 \mathrm{~m}$ above sea-levei and the length measures approximatery $400 \mathrm{~m}$. It is one of the largest caves in this island. In Hoshino-no-ana Cave, wad-minerals occur as powdery black matter of incrustation on the ceiling and coated much of the speleothems.

\section{ANALYTICAL RESULTS}

The materials collected have been examined by X-ray diffraction method. The results of four samples are listed in Table 1.

Comparative abundance order of the heavy metal elements, $\mathrm{Mn}, \mathrm{Fe}, \mathrm{Zn}$ and $\mathrm{Cr}$ have been obtained by X-ray fluorescence analysis. Table 2 gives the preliminary results.

Table 1. Wad-minerals in studied caves

\begin{tabular}{|c|c|c|c|c|}
\hline \multirow{2}{*}{ wad-minerals } & \multicolumn{4}{|c|}{ caves } \\
\hline & na-jama & Dushu-yan & Gan-ze-ze & Hoshino-no-ana \\
\hline \multicolumn{2}{|l|}{ birnessite } & $\mathrm{X}$ & & \\
\hline $10 \AA ̊$-manganite & $\mathrm{X}$ & & & \\
\hline pyrolusite & $\mathrm{X}$ & & & \\
\hline todorokite & $\mathrm{X}$ & & & \\
\hline goethite & $\mathrm{X}$ & & & $\mathrm{X}$ \\
\hline no pearks & & & $\mathrm{X}$ & \\
\hline
\end{tabular}

Table 2. Comparative abur.dance for heavy metal elements of wad-minerals

\begin{tabular}{ll}
\hline Localities & Comparative abundance \\
\hline Najdena-jama Cave & $\mathrm{Mn} \gg \mathrm{Fe}$ \\
Dushu-yan Cave & $\mathrm{Mn} \gg \mathrm{Zn}>\mathrm{Fe}$ \\
Gan-ze-ze Cave & $\mathrm{Mn} \gg \mathrm{Zn}>\mathrm{Fe}>\mathrm{Cr}$ \\
Hoshino-no-ana Cave & $\mathrm{Mn} \gg \mathrm{Fe}>\mathrm{Cr}$ \\
\hline
\end{tabular}




\section{GENESIS OF WAD-MINERALS}

According to Moore and Nicholas (1967), microorganisms (for examples, bacterium Clinothrix putealis) probably play a part in the origin of the black manganese deposits (birnessite and psilomelane) in caves.

Broughton (1972) listed all the cave minerals in the world and, particularily, wad-minerals such as romanechite and/or other hydrous manganese oxides in the cavern environment.

Hill (1976) summarized a number of mineralogical literatures of manganese oxides from cavern environment, and listed some wad-minerals (pyrolusite, birnessite, psilomelane (or hollandite) and heavy metal manganates).

It is not known if these manganese trace impurities are originally present in surface ground water or are dissolved by solutions percolating down through overlying strata. On the other hand, Hill (1976) recognized that some limestones contained noticeable amounts of detritic pyrolusite and a little manganese precipitation was likely caused by evaporation.

The writer has no measured data of dissolved manganese in the surface and underground waters for these studied caves. However, it must be a required process that cave water contain enough manganese to provide a source for the manganese in the wad-minerals.

Although, much less is known about the concentration of manganese, Okafuji et al. (1977), showed that the heavy metal elements data of cave clay deposits and weathering soils of limestones as shown in Table 3. The data of these cave clay and soils do support the view that a manganese concentration in the water may be caused by continental weathering.

On the other hand, mineral calcite has to contain a small amount of $\mathrm{MnCO}_{3}$ when the environments allow, therefore limestones and dolomites which are the mather rocks of solutional caves seem to contain commonly manganese ions. Limestones

Table 3. Heavy metal contents of cave clay deposits and soils (ppm)

\begin{tabular}{llllllll}
\hline Samples & $\mathrm{Mn}$ & $\mathrm{Fe}$ & $\mathrm{Co}$ & $\mathrm{Ni}$ & $\mathrm{Cu}$ & $\mathrm{Zn}$ & $\mathrm{Cd}$ \\
\hline cave clay deposits & 656 & 21,000 & 8.88 & 19 & 63 & 336 & 8.7 \\
soils & $300-800$ & $30,000-50,000$ & $30-60$ & $20-60$ & $100-150$ & $1.0-2.0$ \\
\hline
\end{tabular}

cave clay deposits: Akiyoshi-quarry, Yamaguchi Prefecture.

soils: Karst area of Western Shikoku, Ehime and Kochi Prefectures. 
and dolomites probably enclose much particles of detrital organic impure calcite and non-organically precipitated calcite under the marine environments.

The insoluble residues content of the Daito limestone, including the studies Hoshino-no-ana Cave, ranges from 0.001 to 0.525 weight percent, averaging 0.033 . The fine fractions of residues consist of clay minerals; illite, montmorillolinte, chlorite, kaclinite and vermiculite (Kashima, 1974). The result of the insoluble residues and clay minerals do support the view that a manganese concentration may have been caused by the corrosion of limestones.

\section{ACKNOWLEDGEMENTS}

The writer is much indebted to Dr. Akira Kato and Dr. Satoshi Ma tsubara of the Department of Geology, National Science Museum for laboratory works of mineral identification, and to Dr. Mitsuo Hashimoto of Department of Earth Sciences, Ibaraki University, for his kindly advices of this work and reading the draft.

Sincere thanks are extended to Mr. France Sušteršič of Institut za raziskovanje Krasa Postojna, Mr. Matjaż Puc of Jamarska Slovenija, Yugoslavia and Mr. Shou-Wen Zhou of Institute of Karst, Ministry of Geology, People's Republic of China, for their much helps in the fields.

\section{REFERENCES}

BROUGHTON, P.L. 1972. Secondary mineralization in the cavern environment. Stud. Speleol., 2:191-207.

HII.I. C.A., 1976. Cave minerals. The Speleo Press. Austin.

KASHIMA, N. 1974. Insoluble residues from the Daito limestone of Minamidjato-jima. Mem. Ehime Univ.. (D), 7:79-88. (In Japanese).

KASHIMA, N. 1977. On some calcium magnesium carbonate speleo-minerals in Yugoslavia and Korea. .I. Speleol. Japan. 2:36-42.

KASHIMA, N. and S.W. ZHOU 1981. On some speleo-minerals from the three karst regions in Southern China. Ibid., 6:42-46.

MOORE. G.W. and B.G. NICHOLAS, 1967. Speleology. D.C. Heath and Company, Boston.

OKAFUJI. G., M. MATSUDA and N. KASHIMA, 1977. Note on coloured fossil bone of Myotis sp. from Akiyoshi-quarry, Yamaguchi Prefecture. Chigaku Kenkyu, 23:289-295. (In Japanese). 